\title{
Multi-agent system for monitoring, diagnosis and forecasting the technical system condition with the car as an example
}

\author{
Nikitin N.A., Kizim A.V., Matokhina A.V. \\ CAD Department \\ Volgograd State Technical University \\ Volgograd, Russia \\ nikitin.nikitaa@outlook.com, kizim@mail.ru,matokhina.a.v@gmail.com
}

\begin{abstract}
This paper describes a multi-agent system for monitoring, diagnosis and forecasting the technical system condition with the car as an example. The system consists of four agents: the monitoring agent (collects reports on the condition of the vehicle, handles requests from the user and displays the response), diagnostic agent (reads log files, parses the parameters of the car), forecasting agent (determines the future values of the parameters and diagnoses predicted values), the data collection agent.
\end{abstract}

Keywords- diagnosis, forecasting, technical system, multiagent system.

\section{INTRODUCTION}

This paper describes a multi-agent system for monitoring, diagnostics and forecasting the technical system condition on the example of the car.

The object of automation are the processes of monitoring, diagnostics and forecasting technical system on the example of the car.

Diagnostic processes include:

- Collecting data about the current condition of the car (getting values of the ECU (Electronic Control Unit) sensor of the car);

- Analyzing data from the sensors and determine the current condition of the car (finding data which falls into the working range, into the ranges of acceptable and critical deviation).

Forecasting process include:

- Collecting data about the current condition of the car (getting values of the ECU)

- Analyzing data from the sensors and forecasting possible condition of the car, based on of collected data.

Monitoring processes include the timely detection the current and potential troubleshooting, monitoring their progress and timely notification of failure of staff to develop compensatory measures.

\section{DESCRIPTION OF MULTI - AGENT SYSTEM}

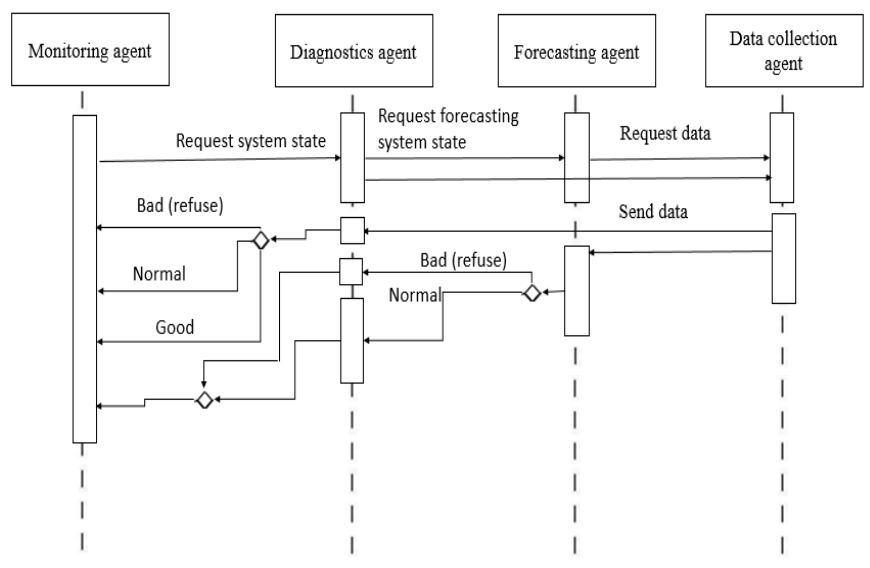

Figure 1. Description of multi - agent system in AUML notation

Monitoring agent is reflexive agent, it collects data about system condition from the diagnostic and forecasting agent.

Diagnostic agent is reflexive agent too, it requests data from data collection agent, processes it, and decides on the current condition of the system, the result is sent to the monitoring agent.

Data collection agent is also reflexive agent it is a hardware and software that reads data from the sensors, stores them, and sends to other agents if necessary.

Forecasting agent is an intelligent agent. The main task of the agent is to predict the possible condition of the system in the future, according to received information.

\section{DATA COLLECTION AGENT}

Data collection agent is a reflexive agent. It is a hardware and software submitted to mobile application Torque and Elm adapter respectively. 
Elm adapter is a device that allows you to read data from the ECU or the vehicle, using OBD-II (On Board Diagnostics) standard, and transfer it to a computer or mobile phone via Bluetooth, Wi-Fi or a special cable, that plugs directly into the adapter and the device [1].

Torque is a mobile application for the Android OS designed to receive and display diagnostic information about the operation of the engine through the OBD-II interface. To connect you need OBD-II Bluetooth adapter [2].

Agent collects information about the condition of the technical system (in this case a car), writes it to a log file in .csv format and sends data to the selected store.

\section{DiAgNOSTIC AGENT}

Diagnostic agent is a reflexive agent. The input which agent receives from the data collection agent is in a .csv format. Data is processed by a specific algorithm and then result is passed to the monitoring agent.

The algorithm of diagnostic agent:

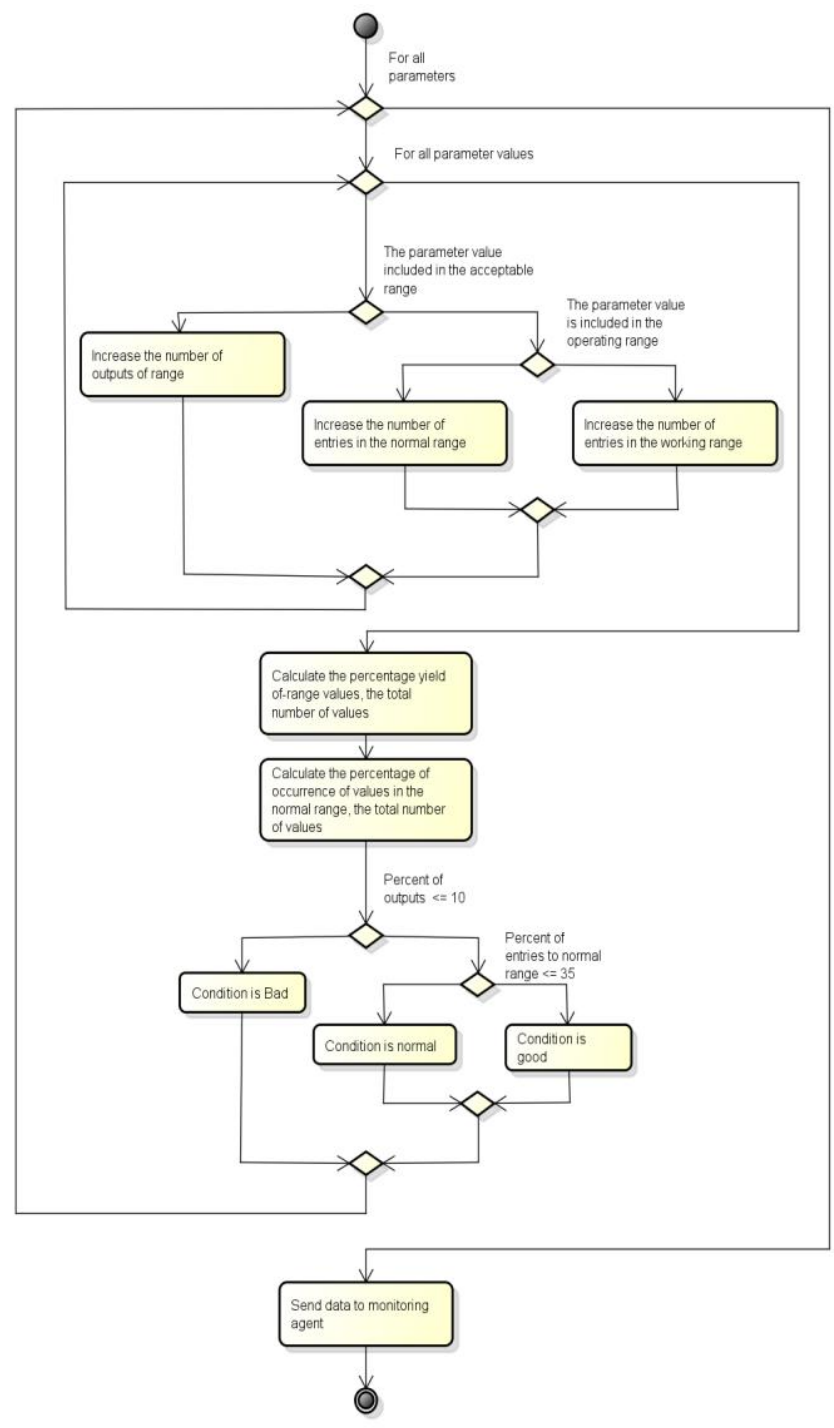

Figure 2. The algorithm of diagnostics agent
To diagnose the condition of the car agent assesses each value of the parameters calculating the number of values, that is out of range, the number of occurrences in the normal range and the number of values within the operating range.

Then the agent calculates percentage of values, which fall within the range of critical deviation and the range of normal deviation, and if the percentage is less than the given (10\%) for the critical or more $(35 \%)$ for normal deviations, the result is bad or normal condition, respectively, otherwise the result is good condition.

\section{FORECASTING AGENT}

Forecasting agent is an intelligent agent. The main task of the agent is to predict the possible condition of the system in the future according to received information.

At the core of the agent is forecasting time series using Arima method.

Agent's work can be divided into two points:

- The agent reads the values from the log file and predicts future values of the parameters, according to log data and using the Arima method;

- Then, the predicted values are subjected to the diagnosis of the condition and according to it agent generates a report.

After forecasting, the agent sends the result to diagnostic agent, which, together with their results, sends them to the monitoring agent.

\section{DESCRIPTION AND JUSTIFICATION OF THE CHOICE OF FORECASTING AND DIAGNOSIS METHODS.}

The method of diagnosis of technical system condition with the car as an example is a step by step analysis of the values of the parameters of the car, calculation the percentage of values falls within the working range, the ranges of acceptable and critical deviation. The method is selected to take into account the entry of parameters in multiple ranges (or range of working values, or in the normal range, or beyond the range of acceptable values), and also take into account that in some very rare cases, the value can go beyond the acceptable ranges even during normal operation system (car), but not to stay permanently.

Selected method of the forecasting is based on the prediction of time series (the Arima method) and it was chosen due to the fact, that it does not require the marked sample data for learning (such as methods, based on the use of neural networks, which is, of course, are more accurate method of forecasting).

\section{DESCRIPTION OF RANGES OF PARAMETERS OF THE TECHNICAL SYSTEM WITH THE CAR AS AN EXAMPLE}

This section describes the parameters of the technical system with the car as an example that are subjected to the diagnosis and prediction. 
TABLE I. TABLE OF RANGES OF PARAMETERS OF THE TECHNICAL SYSTEM ON THE EXAMPLE OF CAR [3]

\begin{tabular}{|c|c|c|c|c|}
\hline Parameter & Units & $\begin{array}{c}\text { The } \\
\text { operating } \\
\text { range }\end{array}$ & $\begin{array}{c}\text { The range of } \\
\text { normal } \\
\text { deviations }\end{array}$ & $\begin{array}{l}\text { The range } \\
\text { of critical } \\
\text { deviations }\end{array}$ \\
\hline $\begin{array}{l}\mathrm{CO} 2 \text { the } \\
\text { average } \\
\text { value of } \mathrm{CO} 2 \\
\text { emissions of } \\
\text { the engine) }\end{array}$ & $\begin{array}{l}\text { Gram }(\mathrm{g}) \\
\text { Kilometer } \\
(\mathrm{km})\end{array}$ & $\begin{array}{l}\text { Less than } \\
130\end{array}$ & About 130 & $\begin{array}{l}\text { More than } \\
130\end{array}$ \\
\hline $\begin{array}{lr}\text { Fuel } & \text { trim } \\
\text { bank } & 1 \\
\text { sensor } & \\
\end{array}$ & $\%$ & {$[-5,5]$} & {$[-15,15]$} & $\begin{array}{l}\text { Other } \\
\text { values }\end{array}$ \\
\hline $\begin{array}{lr}\text { Fuel } & \text { trim } \\
\text { bank } & 1 \\
\text { sensor } & \\
\end{array}$ & $\%$ & {$[-5,5]$} & {$[-15,15]$} & $\begin{array}{l}\text { Other } \\
\text { values }\end{array}$ \\
\hline $\begin{array}{ll}\text { Fuel rail } \\
\text { pressure }\end{array}$ & $\begin{array}{l}\text { Kilogram }(\mathrm{kg}) / \\
\text { centimeter } \\
(\mathrm{cm})\end{array}$ & {$[2.5,3.5]$} & {$[2.2,4]$} & $\begin{array}{l}\text { Other } \\
\text { values }\end{array}$ \\
\hline $\begin{array}{l}\text { The pressure } \\
\text { in the intake } \\
\text { manifold }\end{array}$ & $\mathrm{kP}$ & $\begin{array}{l}{[0,} \\
\text { atmosphere } \\
\text { pressure }]\end{array}$ & $\begin{array}{l}\text { More than } \\
\text { pressure }\end{array}$ & atmosphere \\
\hline Fuel pressure & $\begin{array}{l}\text { Atmosphere } \\
\text { (atm) }\end{array}$ & {$[2,4]$} & & $\begin{array}{l}\text { Less than } 2 \\
\text { or more } \\
\text { than } 4\end{array}$ \\
\hline Longitude & $\%$ & {$[-20,20]$} & & $\begin{array}{l}\text { Less than - } \\
20 \text { or more } \\
\text { than } 20\end{array}$ \\
\hline Latitude & $\%$ & {$[-10,10]$} & & $\begin{array}{l}\text { Less than - } \\
10 \text { or more } \\
\text { than } 10\end{array}$ \\
\hline $\begin{array}{l}\text { Voltage } \\
\text { (control } \\
\text { module) }\end{array}$ & Volt (V) & $\begin{array}{l}\text { Battery } \\
\text { voltage }\end{array}$ & $\begin{array}{l}\text { Battery } \\
\text { voltage }-0.5 \\
\text { V }\end{array}$ & $\begin{array}{l}\text { Other } \\
\text { values }\end{array}$ \\
\hline $\begin{array}{l}\text { Volumetric } \\
\text { efficiency } \\
\text { (rated) }\end{array}$ & $\%$ & {$[80,100]$} & {$[50,100]$} & $\begin{array}{l}\text { Less than } \\
50\end{array}$ \\
\hline $\begin{array}{l}\text { Throttle } \\
\text { Position } \\
\text { (Manifold) }\end{array}$ & $\%$ & Less than 2 & For 2 to 4 & $\begin{array}{l}\text { More than } \\
4\end{array}$ \\
\hline $\begin{array}{ll}\text { Air } & \text { Fuel } \\
\text { Ratio } & \end{array}$ & & $14: 1$ & {$[13: 1,18: 1]$} & $\begin{array}{lr}\text { Less } & \text { than } \\
13: 1 & \text { or } \\
\text { more } & \text { than } \\
18: 1 & \end{array}$ \\
\hline $\begin{array}{l}\text { Intake air } \\
\text { temperature }\end{array}$ & $\begin{array}{l}\text { Degree } \\
\text { Celsius }\left({ }^{\circ} \mathrm{C}\right)\end{array}$ & 25 & {$[20,30]$} & - \\
\hline $\begin{array}{l}\text { Catalyst } \\
\text { temperature }\end{array}$ & $\begin{array}{l}\text { Degree } \\
\text { Celsius }\left({ }^{\circ} \mathrm{C}\right)\end{array}$ & {$[230,300]$} & {$[230,800]$} & $\begin{array}{lr}\text { Less } & \text { than } \\
230 & \text { or } \\
\text { more } & \text { than } \\
800 & \end{array}$ \\
\hline $\begin{array}{l}\text { Engine oil } \\
\text { temperature }\end{array}$ & $\begin{array}{l}\text { Degree } \\
\text { Celsius }\left({ }^{\circ} \mathrm{C}\right)\end{array}$ & {$[80,100]$} & {$[50,150]$} & $\begin{array}{l}\text { Other } \\
\text { values }\end{array}$ \\
\hline $\begin{array}{l}\text { Engine } \\
\text { coolant } \\
\text { temperature } \\
\text { (when the } \\
\text { engine is } \\
\text { operating) }\end{array}$ & $\begin{array}{l}\text { Degree } \\
\text { Celsius }\left({ }^{\circ} \mathrm{C}\right)\end{array}$ & {$[80,90]$} & {$[50,110]$} & $\begin{array}{l}\text { More than } \\
110\end{array}$ \\
\hline $\begin{array}{l}\text { Transmission } \\
\text { temperature }\end{array}$ & $\begin{array}{l}\text { Degree } \\
\text { Celsius }\left({ }^{\circ} \mathrm{C}\right)\end{array}$ & {$[80,100]$} & $\begin{array}{l}\text { [Environment } \\
\text { temperature, } \\
250]\end{array}$ & $\begin{array}{l}\text { More than } \\
250\end{array}$ \\
\hline
\end{tabular}

\section{RESULTS}

The system has been tested on a real car Ford C-Max. Figure 3 shows the piece of data that have been collected by data collection agent within 30 minutes of using the car:

\begin{abstract}
ude, GPS Speed (Meters/second), Horizontal Dilution of Precision, Altitude, Bearing, $G(x), G$ $3.25600004,-0.27700001,9.45199966,-0.02871418,-0.78125,37.85542297,14.93888664,37.85542297$ $3.25600004,-0.27700001,9.45199966,-0.02871418,-0.78125,18,14.93888664,18,0,-,-, 1.06200004$, $3.25600004,-0.27700001,9.45199966,-0.02871418,-3.90625,18.25,14.93888664,18.25,0,1.42236435$ $3.25600004,-0.27700001,9.45199966,-0.02871418,-3.90625,19.79999924,14.93888664,19.79999924$ ， $3.25600004,-0.27700001,9.45199966,-0.02871418,2.34375,21.5,14.93888664,21.5,0,16.89045334$, $3.25600004,-0.27700001,9.45199966,-0.02871418,5.46875,22.8571434,14.93888664,22.8571434,0,1$ $3.25600004,-0.27700001,9.45199966,-0.02871418,0,25.33333397,14.93888664,25.33333397,0,12.77$ $3.25600004,-0.27700001,9.45199966,-0.02871418,0,27,14.93888664,27,0,12.77318382,-7.1310000$ $3.25600004,-0.27700001,0.45199966,-0.02871410,1.5625,27.66666603,14.93808664,27.66666603,0$ $3.2560004,0.2770001,9.4599966,-0.02871418,1.5625,27.6666603,0,12.7731838664,27.66666003,0$ $3.25600004,-0.27700001,9.45199966,-0.02871410,-5.46675,29.0714283,14.93808664,29.0714283,0$ $3.25600004,-0.27700001,9.45199966,-0.02871418,-11.71875,30.5625,14.93888664,30.5625,0,10.95$ $3.25600004,-0.27700001,9.45199966,-0.02871418,-7.03125,31.94444466,14.93888664,31.94444466$, $3.25600004,-0.27700001,9.45199966,-0.02871418,-7.03125,32.5263176,14.93888664,32.5263176,0$, $3.25600004,-0.27700001,9.45199966,-0.02871418,-13.28125,33.52381134,14.93888664,33.52381134$ $3.25600004,-0.27700001,9.45199966,-0.02871418,-16.40625,34.26086807,14.93888664,34.26086807$ $3.25600004,-0.27700001,9.45199966,-0.02871418,-22.65625,34.54166794,14.93888664,34.54166794$ $3.25600004,-0.27700001,9.45199966,-0.02871418,-25.78125,35.03845978,14.93888664,35.03845978$ $3.25600004,-0.27700001,9.45199966,-0.02871418,-18.75,35.42856979,14.93888664,35,42856979,0$ $3.25600004,-0.27700001,0.45199966,-0.02871418,-19.53125,35.55172348,14.93808664,35.55172348$, $3.2500004,-0.2770001,9.4519966,-0.02071410,-19.53125,55.55172340,14.93808664,35.5517234$ $3.2560000,-0.27700001,9.45199966,-0.02871418,-22.65625,35.8064989,14.93886604,35.80644989$
\end{abstract}

Figure 3. Some collected data

The first row contains the names of all parameters. All subsequent lines contain the value of each parameter, if the parameter is not supported, the value is a symbol "-". All parameter names and values separated by a comma.

In our case, we have a file which contains about 1200 lines, which means that we have about 1200 values for each supported parameters.

The system has four operating modes:

1) Help mode, it means that system can display the usage message

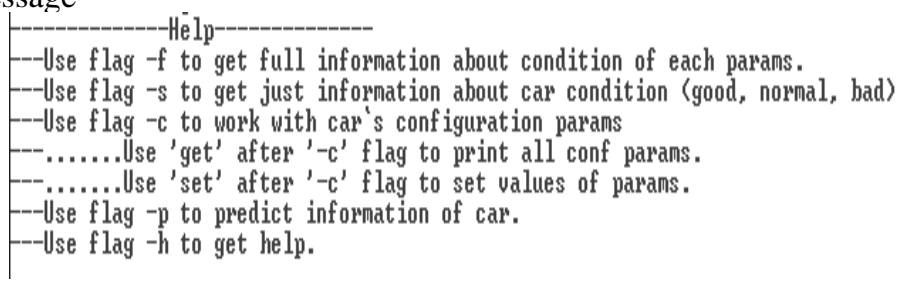

Figure 4. Usage message

2) Short diagnostics mode. It means, that system can display short diagnostics information about condition of the car. We'll get one of the three possible condition of the car:

- $\mathrm{Bad}$

- Normal

- Good

In our case we got a normal condition of the car. It means that one or more parameters are normal, while other parameters are good.

3) Full diagnostics mode. It means, that the system also can display detailed diagnostic information about condition of the car. 
Condition is good by Fuel trim bank 1 sensor 1

Fuel trim bank 1 sensor 2 contain incorrect value. Mybe symbol '-' Condition is good by Intake Manifold Pressure(psi)

Condition is good by Fuel Trim Bank 1 Long Term (\%)

Condition is good by Kilometers Per Litre

Condition is good by Fuel Trim Bank 1 Short Term (\%)

Condition is good Engine Load $(\%)$

Condition is good by Voltage (Control Module)

Condition is good by 02 Volts Bank 1 sensor $1\langle U\rangle$

Condition is good by 02 Volts Bank 1 sensor $2\langle U\rangle$

Condition is good by Air Fuel Ratio (Commanded) (:1)

Condition is good by Intake Air Temperature $\left({ }^{\circ} \mathrm{C}\right\rangle$

Condition is normal by Intake Air Temperature $\left({ }^{\circ} \mathrm{C}\right)$

Condition is good by Engine Coolant Temperature $\left.{ }^{\circ} \mathrm{C}\right\rangle$

Figure 5. Detiled diagnostics information about condition of the car

Thus we see that all the car parameters are in good condition, except for Intake Air Temperature. This parameter is in normal condition.

4) Prediction mode. The system display detailed (just detailed) information about predicted condition of the car.

The result will look very similar to the diagnosed information:

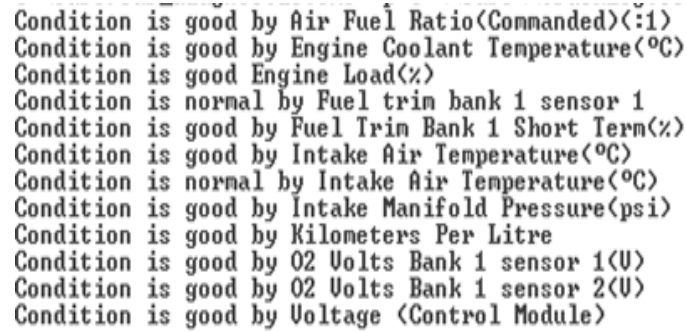

Condition is good by Air Fue l Ratio(Connanded)(:1)

Condition is good by Engine Coolant Tenperature $\left({ }^{\circ} \mathrm{C}\right)$

Condition is good Engine Load(\%)

Condition is nornal by Fuel trin bank 1 sensor 1

Condition is good by Fuel Trin Bank 1 Short Tern(\%)

Condition is good by Intake Air Temperature $\left({ }^{\circ} \mathrm{C}\right)$

Condition is nornal by Intake Air Temperature $\left({ }^{\circ} \mathrm{C}\right)$

Condition is good by Intake Manifold Pressure(psi)

Condition is good by Kiloneters Per Litre

Condition is good by 02 Volts Bank 1 sensor 1(U)

Condition is good by 02 Volts Bank 1 sensor 2(U)

Condition is good by Voltage (Control Module)

Figure 6. Predicted information

According to predicted information we see, that all the car parameters are in good condition, except for Intake Air Temperature and Fuel Trim Bank 1 Sensor 1. These parameters are in normal condition. Parameter Fuel Trim Bank 1 Sensor 1 has a good condition in diagnostic (current condition), but according to predicted information this parameter may be out from operating range, that possible indicates incipient faults.

Solutions for representation of knowledge about technical systems for the purposes of monitoring and diagnosis are created with the financial support of the RFBR (grant № 16-0700635_a, 16-47-340229). Agents program realization solutions is created with the support of the Ministry of Education and Science of the Russian Federation, project number 2.1917.2014K_2014 as a project part of the state assignment.

\section{REFERENCES}

[1] Elm Electronics. ELM327 v2.1. OBD to RS232 Interpreter Integrated Circuit. Elm Electronics Inc., 2014. E-book.

[2] Torque OBD Performance and Diagnostics for your Vehicle / V.F. Ian Hawkins // 2012.

[3] Diagnostics of electronic systems of the car / V.F. Yakovlev // SOLON -Press 2003, vol. A272

[4] Multi-agent systems component-based generator: development approach / A.G. Kravets, A.D. Kravets, S.A. Fomenkov, V.A. Kamaev // Applied Computing 2013 : proceedings of the IADIS International Conference (Fort Worth, Texas, USA, October 23-25, 2013) / IADIS (International
Association for Development of the Information Society), UNT (University of North Texas). - [Fort Worth (Texas, USA)], 2013. - P. 178-182. --.

[5] Decision support in determining of repair actions using fuzzy logic and agent system / M.V. Denisov, A.V. Kizim, V.A. Kamaev, S.V. Davydova // Proceedings of the European Conference on Data Mining 2014 and International Conferences on Intelligent Systems and Agents 2014 and Theory and Practice in Modern Computing 2014 (Lisbon, Portugal, July 15-17, 2014) : part of the Multi Conference on Computer Science and Information Systems 2014 / IADIS (International Association for Development of the Information Society). - Lisbon (Portugal), 2014. - P. 217-221. ---

[6] Organization of the Repair and Maintenance in Road Sector with Ontologies and Multi-agent Systems [Electronic resource] / M.V. Denisov, V.A. Kamaev, A.V. Kizim // Procedia Technology. Vol. 9 : CENTERIS 2013 - Conference on ENTERprise Information Systems / ProjMAN 2013 - International Conference on Project MANagement/ HCIST 2013 - International Conference on Health and Social Care Information Systems and Technologies. - 2013. - P. 819-825. - URL http://www.sciencedirect.com/science/article/pii/S2212017313002454.

[7] Solution on Decision Support in Determining of Repair Actions Using Fuzzy Logic and Agent System / M.V. Denisov, A.V. Kizim, V.A Kamaev, S.V. Davydova, A.V. Matokhina // Knowledge-Based Software Engineering : Proceedings of 11th Joint Conference, JCKBSE 2014 (Volgograd, Russia, September 17-20, 2014) / ed. by A. Kravets, M. Shcherbakov, M. Kultsova, Tadashi Iijima ; Volgograd State Technical University [etc.]. - : Springer International Publishing, 2014 - P. 533-541. - (Series: Communications in Computer and Information Science ; Vol. 466). ---

[8] A Conceptual Agent-Based Model to Supporting the Production Equipment Technical Service and Repair Organization / A.V. Kizim, M.V. Denisov, S.V. Davydova, V.A. Kamaev // CENTERIS / ProjMAN / HCist 2014 (Troia, Portugal, 15-17, October 2014) : book of industry papers, poster papers and abstracts / University of Minho, International Project Management Association [et al.]. - Troia (Portugal), 2014. - P. 119. ---

[9] Development of Ontological Knowledge Representation Model of Industrial Equipment / A.V. Kizim, A.V. Matokhina, B. Nesterov // Creativity in Intelligent Technologies and Data Science. CIT\&DS 2015 : First Conference (Volgograd, Russia, September 15-17, 2015) : Proceedings / Springer International Publishing, 2015. - P. 355-367. (Ser. Communications in Computer and Information Science. Vol. 535).

[10] Establishing the Maintenance and Repair Body of Knowledge: Comprehensive Approach to Ensuring Equipment Maintenance and Repair Organization Efficiency [Electronic resource] / A.V. Kizim // Procedia Technology. Vol. 9 : CENTERIS 2013 - Conference on ENTERprise Information Systems / ProjMAN 2013 - International Conference on Project MANagement/ HCIST 2013 - International Conference on Health and Social Care Information Systems and Technologies. - 2013. - P. 812-818. - URL http://www.sciencedirect.com/science/article/pii/S2212017313002442.

[11] Intellectual information support for operation of technical systems based on ontological engineering / V.V. Panteleev, A.V. Kizim, A.V. Matokhina, V.A. Kamaev // CENTERIS / ProjMAN / HCist 2015 : book of industry papers, poster papers and abstracts (Vilamoura, Portugal, October 7-9, 2015) / [Polytechnic Institute of Cavado and Ave (Portugal), University of Minho (Portugal)] [et al.]. - [Б/м ; publisher: SciKA], 2015. - P. 93. -

[12] Application of a Production a Network for Obtaining Information on the Reasons of Appearance of Defects and Ways of its Elimination / A.V. Matokhina, A.V. Kizim// Research Journal of Applied Sciences. - 2015. - Vol. 10, No. 1. - C. 1-6.

[13] A Survey of Forecast Error Measures / Shcherbakov, M.V., Brebels, A., Shcherbakova, N.L., Tyukov, A.P., Janovsky, T.A., Kamaev, V.A. // World Applied Sciences Journal (WASJ). - 2013. - Vol. 24, Spec. Issue 24 : Information Technologies in Modern Industry, Education \& Society. - C. 171-176.

[14] Establishing the maintenance and repair body of knowledge: comprehensive approach to ensuring equipment maintenance and repair organization efficiency / A.V. Kizim // Book of industry papers, poster papers and abstracts of the CENTERIS 2013 - Conf. on Enterprise 
Information Systems / ProjMAN 2013 - International Conf. on Project MANagement / HCist 2013 - International Conf. on Health and Social Care Information Systems and Technologies (Lisbon, Portugal, 23-25 October, 2013) / Polytechnic Institute of Cavado and Ave [et al.]. Lisbon, 2013. - P. 85. -

[15] Use of fuzzy neural networks for technical diagnostics of road machinery [Electronic resource] / O. Viktorova // Bulletin of Kharkiv National Automobile and Highway University. - 2012. Vol 5.

[16] A logical approach to the definition of probalistic logic coefficient trouble-shooting cars / Lyandenbursky V.V., Tarasov A.I., Seyfetdinov R.R. // Bulletin of Orenburg State University. - 2013. Vol 4.

[17] Chowanietz E. Automobile electronics. - Society of Automotive Engineers, Inc, 1995, 246 pp. 2.

[18] Tom Denton. Automobile electrical and electronic systems. - Society of Automotive Engineers, Inc., 1995. 312 pp. 4. William B. Ribbens. Understanding automotive electrpnics. - ButterworthHeinemann, 1998. $434 \mathrm{pp}$.

[19] On-board diagnostics / W. Rokosz // StarSPB, Behind the wheel Publishing. - 2013, Vol. 224.

[20] Organization of the repair and maintenance in road sector with ontologies and multi-agent systems / M.V. Denisov, V.A. Kamaev, A.V. Kizim // Book of industry papers, poster papers and abstracts of the CENTERIS 2013 - Conf. on Enterprise Information Systems / ProjMAN 2013 - International Conf. on Project MANagement / HCist 2013 - International Conf. on Health and Social Care Information Systems and Technologies (Lisbon, Portugal, 23-25 October, 2013) Polytechnic Institute of Cavado and Ave [et al.]. - Lisbon, 2013. - P. 94. 
